\title{
Deep structure of an open sea eddy in the Algerian Basin
}

\author{
S. Ruiz ${ }^{\mathrm{a}, *}$, J. Font $^{\mathrm{a}}$, M. Emelianov ${ }^{\mathrm{a}}$, J. Isern-Fontanet $^{\mathrm{a}}$, C. Millot $^{\mathrm{b}}$, \\ J. Salas ${ }^{\mathrm{a}}$, I. Taupier-Letage ${ }^{\mathrm{b}}$ \\ a Institut de Ciències del Mar (CMIMA-CSIC), P. Maritim 37-49, 08003 Barcelona, Spain \\ ${ }^{\mathrm{b}}$ Laboratoire d'Océanographie et de Biogéochimie, COM-CNRS, BP330, 83507 La Seyne-sur-Mer, France
}

Received 16 November 2000; accepted 1 August 2001

\begin{abstract}
The Algerian Basin dynamics is dominated by the presence of very energetic mesoscale structures. Deep open sea eddies are key features that influence the regional circulation of water masses at all depths. In May 1998, an open sea eddy was sampled near $38^{\circ} \mathrm{N} 2^{\circ} \mathrm{E}$ by means of CTD, Acoustic Doppler Current Profiler (ADCP) and surface Lagrangian drifters. For the first time, it has been possible to characterise one of these mesoscale structures in its full depth, down to $2800 \mathrm{~m}$. The density distribution indicated the presence of lighter water in the centre of the eddy from the surface to the bottom. The direct velocity measurements in the surface layer, plus the determination of the baroclinic shear from CTD data, evidenced that the anticyclonic motion was present in the whole water depth. (C) 2002 Elsevier Science B.V. All rights reserved.
\end{abstract}

Keywords: Mesoscale eddies; Hydrographic measurements; Lagrangian buoys; ADCP; Altimetry; Deep circulation; Mediterranean Sea; Algerian Basin

\section{Introduction}

The Algerian Basin occupies most of the southern part of the western Mediterranean Sea. Due to its geographic characteristics, the Algerian Basin dynamics is dominated by the interaction between light waters of recent Atlantic origin and the resident denser waters. The major feature of its circulation is the Algerian current (AC), the alongslope flow that drives the Modified Atlantic Water (MAW), incoming from

\footnotetext{
* Corresponding author. Present affiliation: Instituto Mediterráneo de Estudios Avanzados, (CSIC-UIB), Palma de Mallorca, Spain. Tel.: +34-971-611732; fax: +34-971-611761.

E-mail address: simon.ruiz@uib.es (S. Ruiz).
}

Gibraltar, to the rest of the western and eastern Mediterranean Basins (Millot, 1985). Due to complex hydrodynamical processes, baroclinic/barotropic instability mainly, this alongslope current generally develops meanders as soon as $0-1^{\circ} \mathrm{E}$, creating an upwelling cell and an anticyclonic eddy inside. Usually, a shallow and short-lived cyclonic circulation also develops upcrest of the meander (Millot, 1999), while the meander itself is the most energetic part of the mesoscale structure. Anticyclonic eddies can rapidly grow up to $50-100 \mathrm{~km}$ in diameter, and drift eastwards along the slope at a few $\mathrm{km} /$ day. In some cases, they are associated to a bigger deep anticyclonic circulation (Millot, 1994; Millot et al., 1997; Obaton et al., 2000). They are then called events, and are generated only a few times a year. Most of these energetic events are 
forced by topography, at the entrance of the Sardinia channel, to drift seawards where both surface and deep eddies merge and become large open sea anticyclonic eddies (100-200 km diameter). Subsequently, they tend to drift back to the west, hence depicting a large counterclockwise circuit. These mesoscale structures (Algerian Eddies, AE) have been observed since the 1980s in satellite infrared images (Taupier-Letage and Millot, 1988), and can last for many months or even years (Puillat et al., 2002) while strongly interacting with the AC. They play a major role in the configuration of the general circulation and the distribution of water masses and biogeochemical parameters and, hence, of the ecosystems, in the Algerian Basin. For example, due to interactions between an $\mathrm{AE}$ and the $\mathrm{AC}$, the latter can flow perpendicularly to the coast for months (Millot et al., 1997; Taupier-Letage and Millot, 1988), while, without any major interactions, it "steadily" flows alongslope (Font et al., 1998a). This gives the unique character of the Algerian Basin dynamics compared to other Mediterranean regions: the path and the structure of the flow can change suddenly and for a long time, being then dominated by the presence of very energetic structures at mesoscale (Fig. 1).

One of the objectives of the Mass Transfer and Ecosystem Response (MATER) project (1996-1999) in the framework of the EU MAST programme was the interdisciplinary study of the mesoscale instabilities generated by the AC. This included a series of cruises in the west (ALGERS) and the east (ELISA, Taupier-
Letage, 2000) of the basin. The first ALGERS cruise, carried out in October 1996, focused on sampling a coastal instability (see Morán et al., 2001 for major details), while the second one, presented here aimed at sampling an open sea eddy. The main goal of the present paper is to study the surface and deep structure of the eddy using an exhaustive multi-sensor sampling strategy. The work is structured as follows: Section 2 includes the description of data set; Section 3 describes the methodology of analysis performed on the data. The results are presented in Section 4, and finally, the summary and discussion are given in Section 5.

\section{Data set}

From 18 to 27 May 1998, an oceanographic cruise was carried out on board the Spanish R/V Hespérides. A large surface eddy, nearly $140 \mathrm{~km}$ in diameter, had been detected by the end of April in NOAA SST images centred at $38^{\circ} \mathrm{N} 2^{\circ} \mathrm{E}$. Its thermal signature depicted a clear anticyclonic structure (Fig. 2). Successive satellite images indicated it was moving to the west at about $2-3 \mathrm{~km} /$ day. Thanks to an onboard satellite receiving station (Sea Space Terascan HRPT), the surface thermal structure was precisely located during the survey. The strategy of the cruise was designed in order to cross the eddy in different directions with underway measurements (thermosalinograph, ADCP, XBTs and a towed undulating CTD in the top $120 \mathrm{~m}$ ).

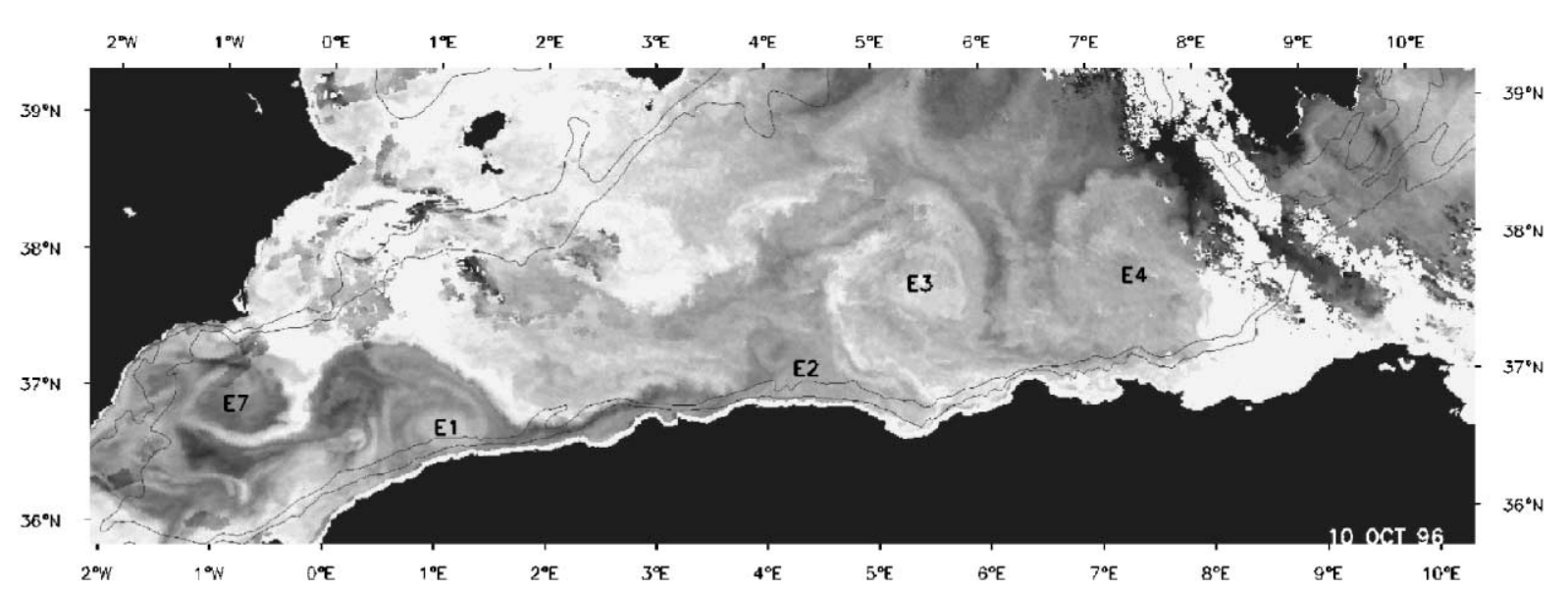

Fig. 1. Infrared image of the Algerian Basin in October 1996. Several coastal and open sea eddies can be identified (from Salas, 1999). 


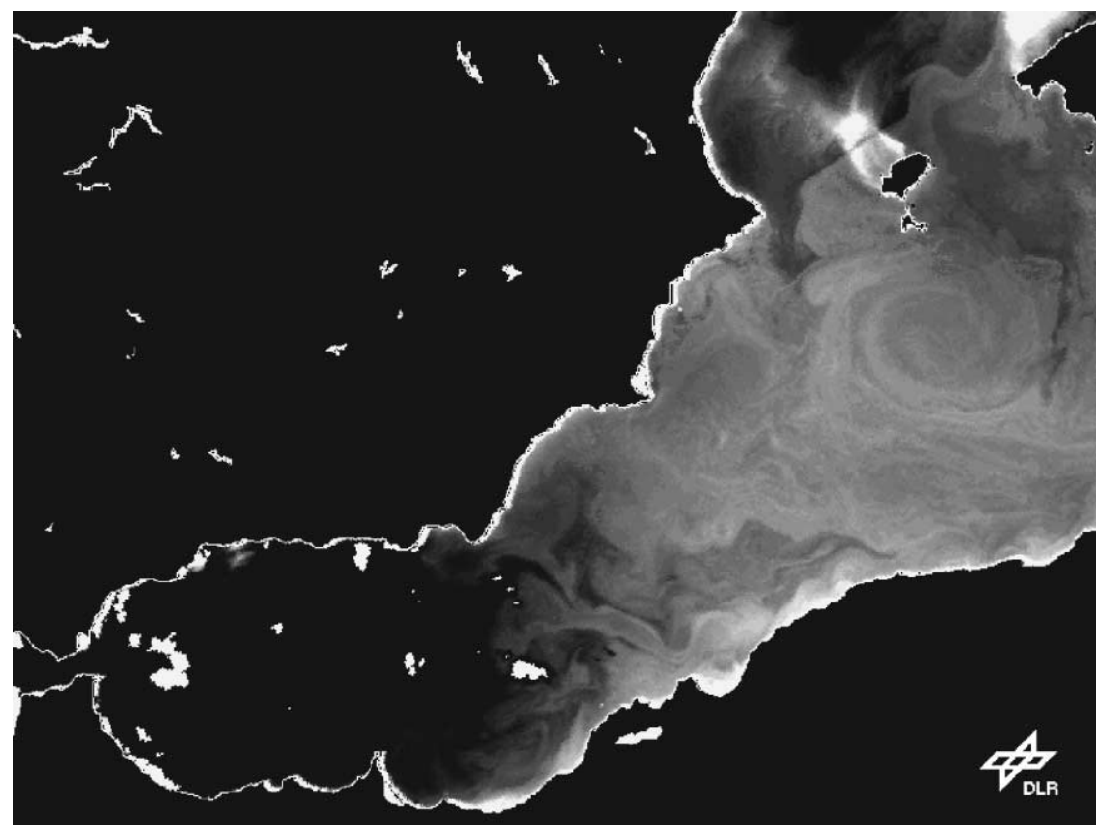

Fig. 2. Sea surface temperature of the Alboran Sea and western Algerian Basin as measured by NOAA/AVHRR on 7 May 1998. The anticyclonic eddy can be observed south of the Balearic Islands. Image downloaded from the DLR GISIS public server.

\subsection{Hydrographic data: $C T D$}

Three CTD transects (Neil Brown Mark III probe, resolution $\left.\Delta T=0.001{ }^{\circ} \mathrm{C}, \Delta S=0.001\right)$ were performed perpendicularly to the Balearic islands southern slope (Fig. 3) with stations 5 nautical miles apart: one along the diameter of the eddy (with casts down to a few metres from the bottom), and two $\sim 45 \mathrm{~km}$ apart on both sides (casts alternatively to the bottom and to $1000 \mathrm{dbar}$ ). Salinity/density calculations, data processing and more technical details are the same than for other cruises on board R/V Hespérides, as given in Font et al. (1998b). Final profiles were interpolated with a vertical resolution of $1 \mathrm{~m}$.

\subsection{Velocity data: VM-ADCP and surface drifters}

Direct velocity measurements in the surface layer were made by two means: a Vessel Mounted Acoustic Doppler Current Profiler (VM-ADCP $150 \mathrm{kHz}$ from RD Instruments) and surface drifters. The VM-ADCP, which was continuously operating, was configured with a 4-m depth cell and a total of 80 cells (maximum depth profile of $328 \mathrm{~m}$ ). The velocity profiles were averaged in 10-min intervals. Using differential GPS positioning, as well as precise heading correction by means of a 3D GPS, we have computed high accuracy absolute current profiles in the top $200 \mathrm{~m}$ (see for instance Griffiths (1994) for a detailed description of the impact of heading error on ADCP velocities). Below this depth, the quality of the echo signal is not good enough to obtain precise current velocities. The mean error in ADCP velocities induced by gyrocompass heading dependence error was estimated in $4-5 \mathrm{~cm} \mathrm{~s}^{-1}$ (Ruiz, 2000). Similar errors on ADCP data have been found in other cruises using the same configuration acquisition and equivalent processing methodology (see Allen et al., 1997). It should be pointed out that in this part of the Mediterranean, the tidal current and inertial oscillations are weak (a few centimetres per second). Therefore, no specific filtering of tidal and inertial oscillation was performed.

Fifteen surface drifting buoys were released across the eddy following the almost north-south diameter along the central CTD transect at stations \#4 to \#18. They were of the classical TOGA-WOCE standard type, drogued with a 10-m long holy sock at a mean depth of $10 \mathrm{~m}$. The drifters' positions, tracked by 


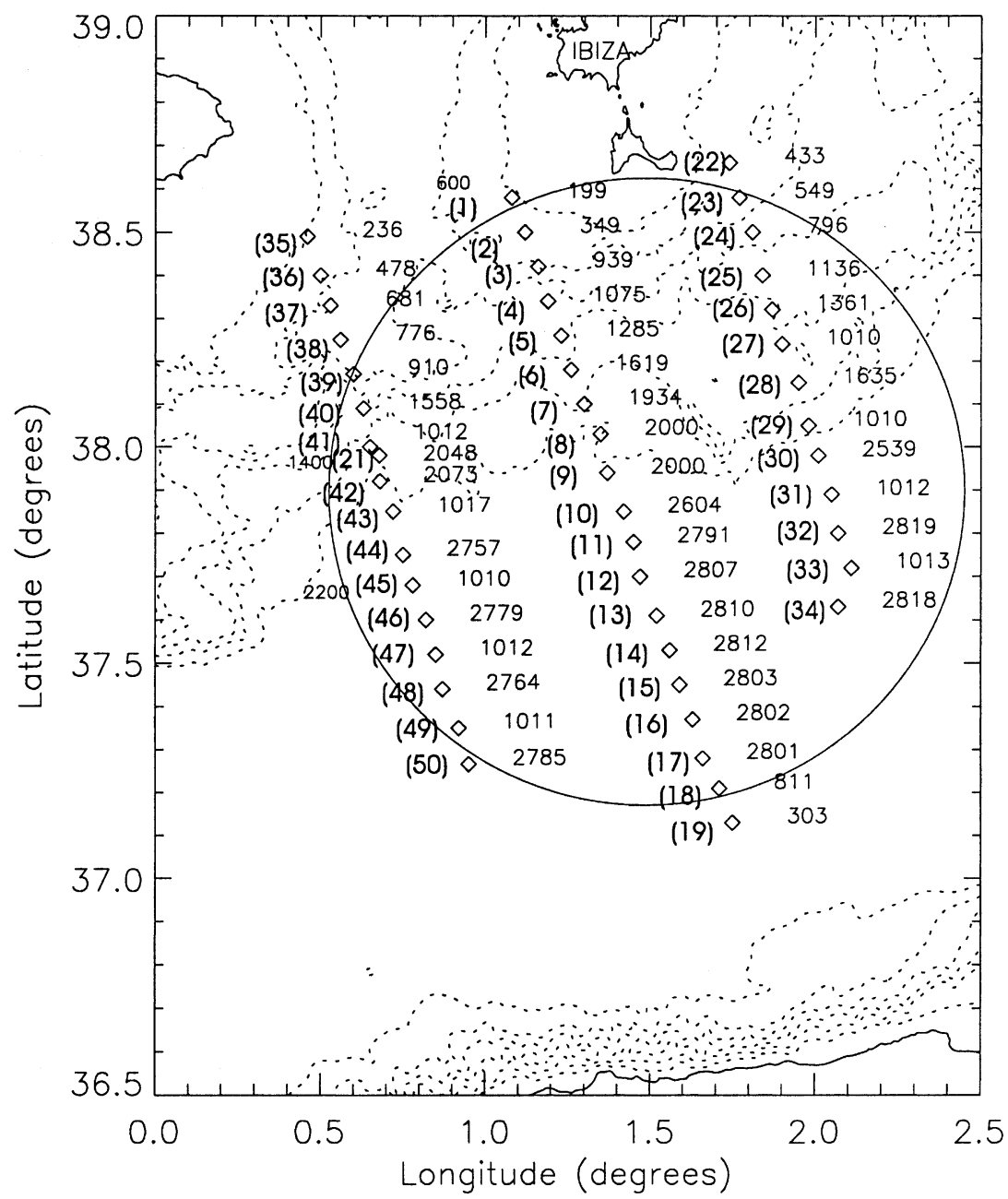

Fig. 3. Study area south of Ibiza and Formentera Islands, with the bathymetry, CTD stations (cast depth indicated on the right and numeration on the left) and position of the eddy according to its SST signature.

satellite, were received directly on board with the HRPT station, and through the ARGOS service after the end of the cruise (more technical details can be found in Salas, 1999).

\subsection{Altimeter data}

Radar altimeters can measure the instantaneous sea level with an error of a few centimetres. This accuracy is adequate to observe big eddies in the open oceans, but close to the threshold for detecting mesoscale structures in most of the Mediterranean. However, the
Algerian Basin is an exception to this since the open sea eddies at this area are big ( $\sim 100 \mathrm{~km}$ in radius) and strong $(50 \mathrm{~cm} / \mathrm{s}$ as a maximum speed) enough to allow a correct altimeter identification (Iudicone et al., 1998; Bouzinac et al., 1998; Fuda et al., 2000). Although tides and atmospheric effects can be modelled and filtered out from altimeter data, the lack of a precise geoid knowledge does not allow the use of absolute sea level measurements but only anomalies in respect to a temporal average. The energetic character of the Algerian Basin, and the consequent absence of permanent flows off the Algerian coast, allow the sea level ano- 


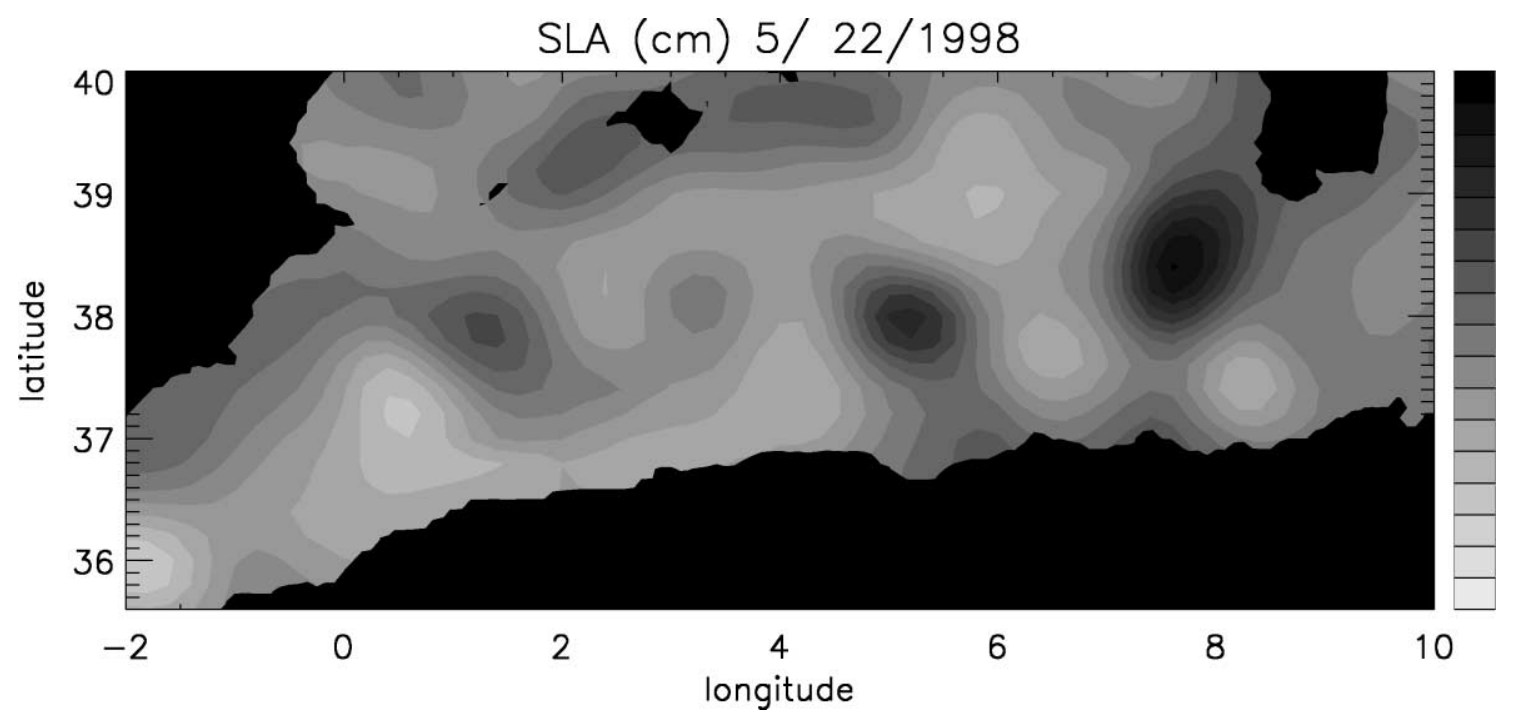

Fig. 4. Sea level anomaly map generated with ERS2 and Topex/Poseidon altimeter data on 22 May 1998.

malies (SLA) to fully describe the circulation features. Fig. 4 is the SLA map of the Algerian Basin closest to the cruise dates (18-27 May 1998), where the eddy sampled during the cruise can be identified near $38^{\circ} \mathrm{N}$ $1.5^{\circ} \mathrm{E}$.

A series of SLA maps of combined ERS plus Topex/Poseidon (T/P) have been used. As ERS has a repeat cycle of 35 days and Topex/Poseidon of 10 days, the analysed SLA maps are produced at intervals of 10 days. The interpolated SLA maps have been provided by CLS, Toulouse. The maps of SLA, combining T/P and ERS data, have been interpolated on a regular $0.2^{\circ} \times 0.2^{\circ}$ grid using a suboptimal space/time objective analysis (Bretherton et al., 1976) which takes into account along-track correlated errors (for a more detailed description of this mapping technique see Le Traon et al. (1998)).

\section{Univariate objective analysis}

The higher precision measurements made in the 49 fixed CTD stations were objectively interpolated using a successive correction scheme (Pedder, 1993) to a regular grid of $8 \times 8 \mathrm{~km}$. The scheme uses a simple Gaussian correlation model with a characteristic length scale of $25 \mathrm{~km}$, which was computed from observed data (figure not shown). The method assumes no correlation between error variance and isotropic correlation over the scattered data distribution. A horizontal filter is applied in order to remove non-resolved structures. This filter consists in a convolution of the Gaussian correlation model with a normal-error filter. We used a cutoff wavelength of 90 $\mathrm{km}$ that is imposed by the mean distance between adjacent transects $(\sim 45 \mathrm{~km})$.

The same objective analysis scheme used with CTD data has been applied to construct gridded horizontal fields of velocity from ADCP measurements, as well as from geostrophic computations. Drifters' velocities, computed from successive satellite locations, have also been filtered and interpolated to the same grid.

\section{Analysed fields}

\subsection{Hydrographic results}

Fig. 5a shows the potential temperature, salinity and potential density (sigma-theta) in the top 500 dbar along the central section. The structure of the isolines is typical of an anticyclonic eddy. Due to the development of the seasonal thermocline (May is 

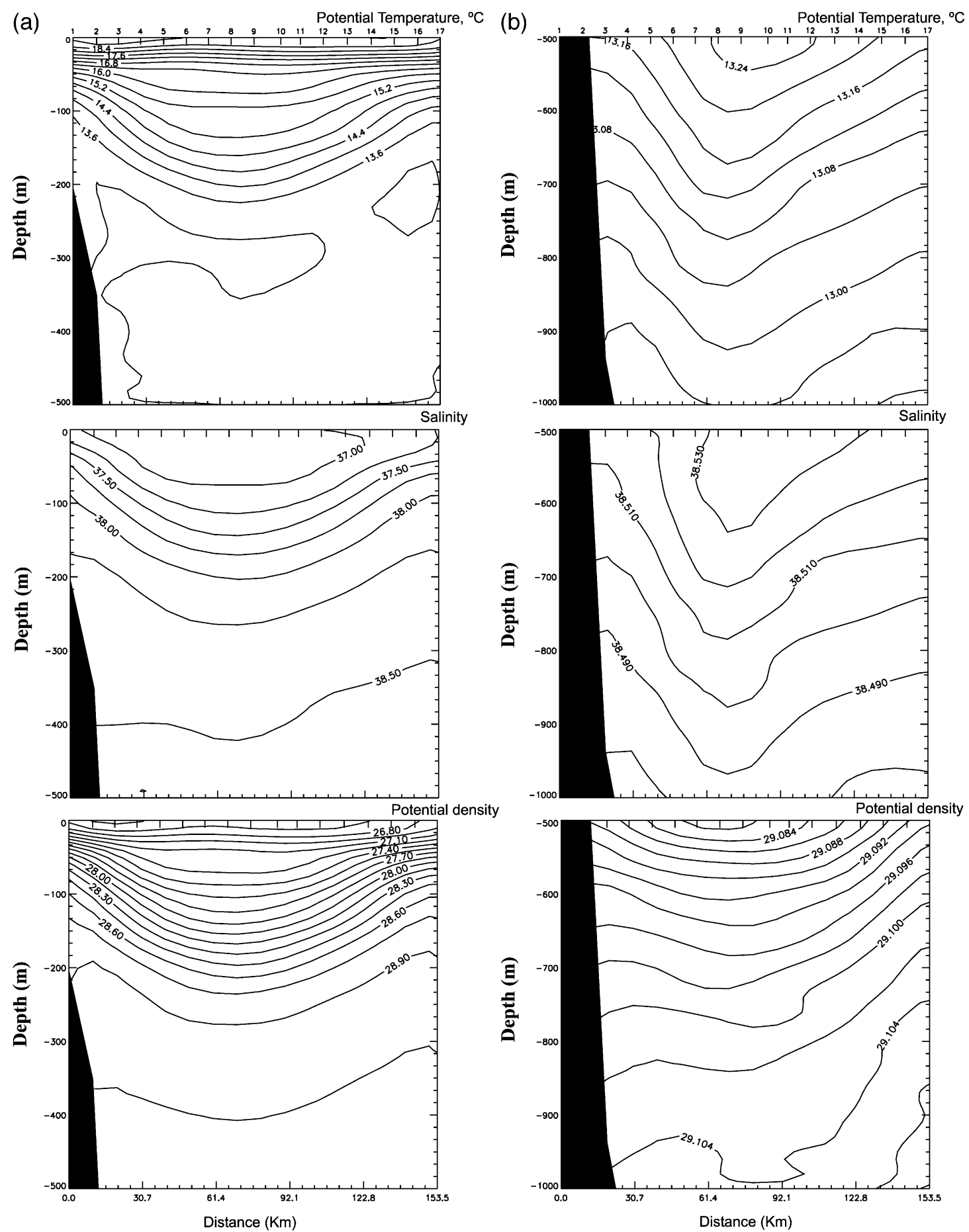

Fig. 5. Vertical distribution of potential temperature, salinity and sigma-theta measured with CTD across the centre of the eddy in a cross-slope (almost N-S) direction: (a) in the top $500 \mathrm{dbar}$, (b) between 500 and $1000 \mathrm{dbar}$ and (c) from 1000 to $2800 \mathrm{dbar}$. The separation between isolines is not constant, to better display the gradients. 
(c)
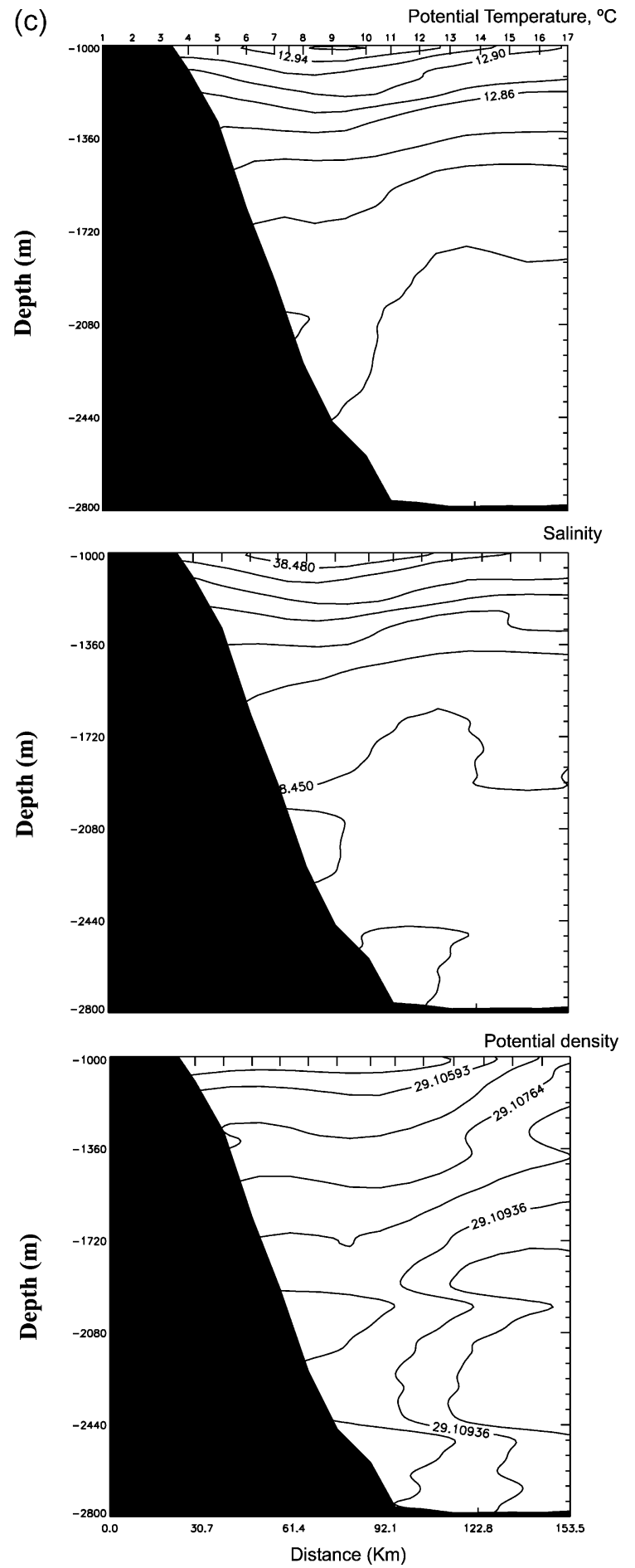

Fig. 5 (continued). usually the month with the most intense increase in surface temperature), salinity displays more clearly this characteristic. In the centre of the eddy, an almost homogeneous salinity layer $(36.9-37.0)$ is found in the top 80 dbar, while in the outer edge surface, salinity is about 37.4. Below 300 dbar for temperature, and 400 dbar for salinity, the presence of Levantine Intermediate Water (LIW) is indicated by the presence of relative and absolute maxima, respectively. In this central section, the LIW core values $\left(\theta=13.45^{\circ} \mathrm{C}\right.$ at $360 \mathrm{dbar}, S=38.55 \mathrm{psu}$ at $\left.460 \mathrm{dbar}\right)$ are found near the centre (slightly south of it), although higher salinity values (38.56 at 380-400 dbar) were detected in the eastern section. These values are very similar to those measured by Benzohra and Millot (1995b) in an open sea eddy around $5^{\circ}$ in May-June 1986, and that appeared to be clearly higher than in surrounding waters. This is a clear indication of a possible "unstructured" LIW distribution, i.e. it forms filaments everywhere in the interior so that this accounts for the eddy action on the LIW in the Algerian Basin and contradicts a LIW-westwardflowing vein.

In the layer 500-1000 dbar (Fig. 5b) the deepening of isotherms, increased by the relative LIW maximum just above, is considerable: $13^{\circ}$ is found at $930 \mathrm{dbar}$ in the centre of the eddy and some 150 dbar above on both sides. The salinity, due to the presence of LIW until 500-600 dbar, is now decreasing with depth, which is the typical situation for the Mediterranean. As LIW was found mainly in the centre (core values) and the southern half of the section, the isohalines display an asymmetrical deepening: the saltier water in the centre is found $130 \mathrm{dbar}$ above in the southern edge and 180 dbar in the northern edge (e.g. 38.50 isohaline). In spite of this salinity distribution acting to increase the density in the centre, the temperature effect dominates and the isopycnals continue to indicate the presence of light waters surrounded by denser ones. The horizontal gradients have even increased in the southern part of the eddy: from a slope of $1.5 \mathrm{~m} /$ $\mathrm{km}$ for the 28.5 isopycnal (at $200 \mathrm{dbar}$ in the centre) to $2.3 \mathrm{~m} / \mathrm{km}$ for 29.1 (790 dbar).

The structure of lighter (warmer, although saltier) water in the centre with respect to the southern part is maintained in the deep layers (Fig. 5c). However, isolines tend to become horizontal when approaching the slope, and below 1300-1400 dbar both isotherms 
and isohalines appear tilted in a typical shelf/slope front position with only an undulation marking the respectively maximum/minimum values in the centre of the eddy. Their opposite effects on density result in a distribution of sigma-theta curves that still present a strong and not so asymmetrical deepening, so that the conditions for an anticyclonic motion are maintained. The slope of isopycnals is $3.5-4 \mathrm{~m} / \mathrm{km}$ on both sides when they are near $1200 \mathrm{dbar}$ in the centre. Below $2000 \mathrm{dbar}$, the centre of the eddy is only $10-15 \mathrm{~km}$ from the continental slope, and the thermal structure appears as relatively warm water between the centre and the slope, and colder $\left(-0.015^{\circ}\right)$ water outside separated by a marked front (more than $30 \mathrm{~m} / \mathrm{km}$ ). In density we can only distinguish light water close to the slope and heavier $\left(+0.002 \sigma_{\theta}\right)$ offshore. This is illustrated by a comparison (Fig. 6) of the deep $\sigma_{\theta}$ profiles between a station in the centre of the eddy (\#10) and one in the southern edge (\#17). Stations situated at an equivalent radial distance from the centre in the other two transects (\#34, \#50 in the southern edge and \#26 in the slope) show a deep profile very similar to \#17. The evident instability of the density field observed on vertical plots (Fig. 5c, potential density) is likely an artifact produced by the analysis scheme because of its $2 \mathrm{D}$ character. That is, the analysis interpolation is performed independently

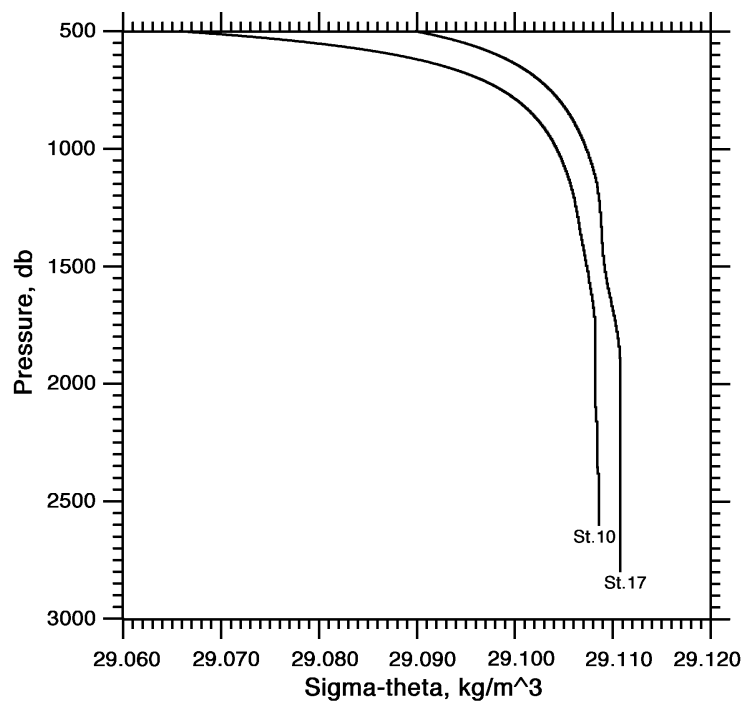

Fig. 6. Comparison between the deep part of one density profile in the centre of the eddy (\#10) and one in its outer edge (\#17). for each defined level, without any connection between them, which makes the algorithm to not exploit the vertical coherence of the data (this limitation has also been reported recently by other authors (Gomis et al., 2001)). Additionally, in this particular case, we have to keep in mind that at low levels there are few available data. However, it is worth remarking that horizontal distribution of density at different depths (Fig. 7) confirms the nearly circular structure with lighter water in the centre. This pattern is maintained down to the bottom, in spite of the intersection with the continental slope.

$\theta-S$ diagrams of stations in the centre of the eddy compared to others from the Algerian current and open Algerian Basin (Fig. 8) indicate the different stages of MAW mixing. Like the one measured in the eastern Algerian Basin during ELISA in 1997 (Taupier-Letage, 2000), the salinity in the surface layer in the centre of our eddy lies between the low values of the Algerian current (36.6 in October 1996) and the higher at open sea locations (37.2-37.9 in different cruises). This clearly accounts for the origin of the eddy from the Algerian current and its further drift in the open basin. The origin and trajectory specified by Isern-Fontanet et al. (2000) using a retrospective analysis of satellite thermal imagery and altimeter sea level anomaly maps, which showed that the trajectory had not been a typical one, is confirmed by the present analysis. Instead of having been released offshore in the channel of Sardinia, it detached in February 1998 from another big anticyclonic eddy that was in contact with the coast near $4-5^{\circ} \mathrm{E}$.

Concerning the detected LIW, it is less mixed in the centre of the eddy than in other areas of the western Algerian Basin, but more than in open sea eddies in the eastern basin as those sampled during ELISA. These results are consistent with the water masses distribution found in previous studies (Benzohra and Millot, 1995a; Emelianov et al., 1999).

\subsection{Velocity results}

\subsubsection{Surface velocity}

The trajectories of the buoys (Fig. 9) immediately indicated an anticyclonic sense of rotation with the centre very close to station $\# 9$, since the drifter launched at that position experienced almost no motion. A comparison of the successive positions of 

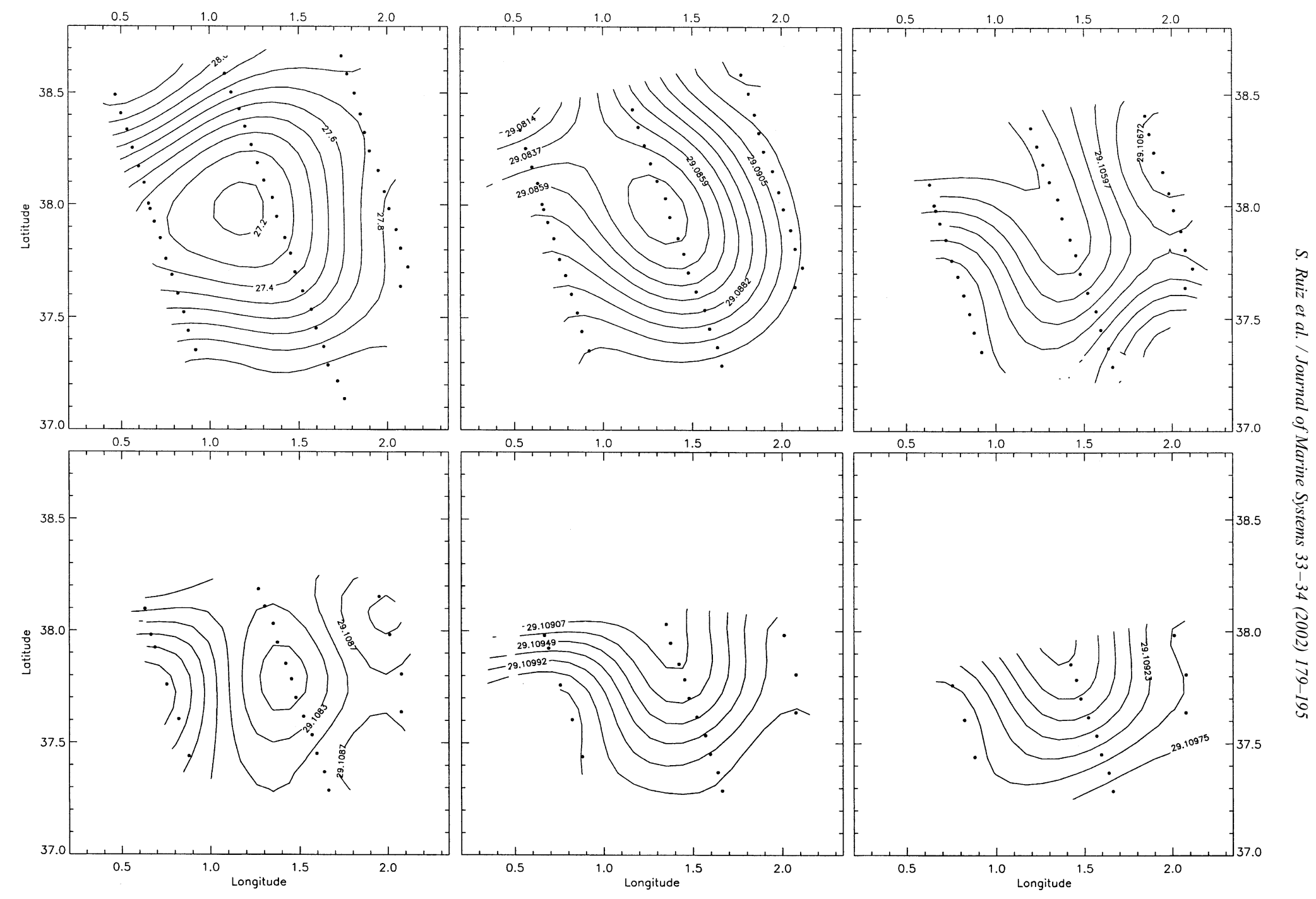

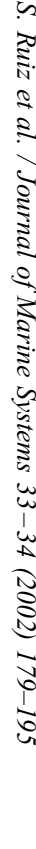

Fig. 7. Objectively analysed density distributions at different depths from data recorded with CTD at fixed stations. From left to right and top to bottom: 50, 500, 1000, 1500, 2000 and $2500 \mathrm{dbar}$ 


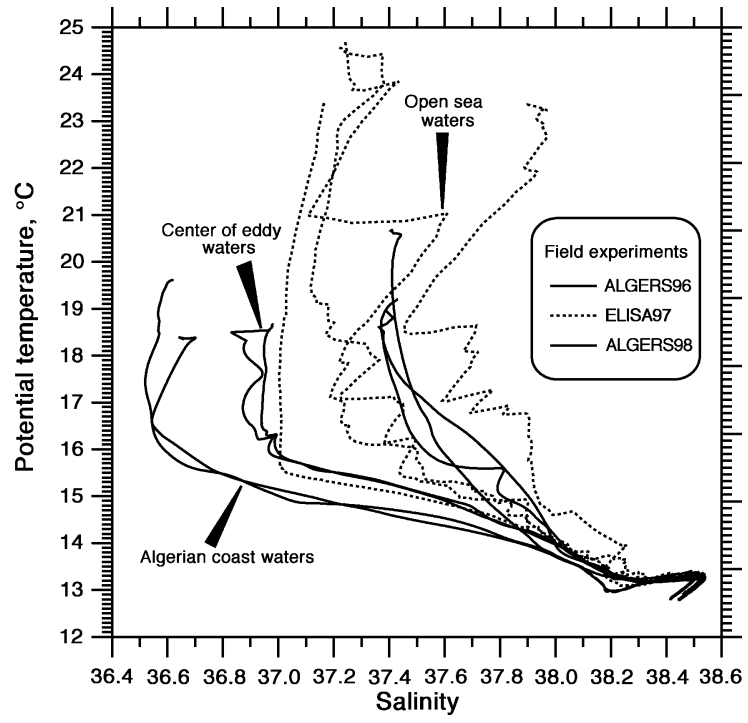

Fig. 8. $\theta-S$ diagrams from CTD casts inside eddies, in the Algerian current, and at open sea in the Algerian Basin (from several MATER cruises 1996-1998).

the different drifters presents the image of an almost solid-body rotation in an inner zone of $80-\mathrm{km}$ diameter (nine drifters). The rotation speed (Fig. 10) is slowly increasing (periods from 3 to 6 days) from the centre to the edge of this inner zone, where the tangential velocity is $40 \mathrm{~cm} \mathrm{~s}^{-1}$ in the north and 50 $\mathrm{cm} \mathrm{s}^{-1}$ in the south. Only in the southern part of the transect, where drifters were launched at greater distances from the centre, the outer part could be characterised (stations \#14-\#18). At a diameter of 100 $\mathrm{km}$, the period is 8 days and the speed has decreased to $40 \mathrm{~cm} / \mathrm{s}$. Beyond this point, the speeds continue to decrease (by approximately $5 \mathrm{~cm} \mathrm{~s}^{-1}$ every $10 \mathrm{~km}$ ) but the trajectories are not closed. That is, the four external drifters, in spite of following initially an anticyclonic motion, tend to leave tangentially the eddy (Fig. 9). However, two of them will be trapped again in early June due to a topographic effect and the drift of the eddy to the west.

Fig. 11 presents the horizontal distribution of the velocity vectors from $A D C P$, averaged every $10 \mathrm{~min}$, at $10 \mathrm{~m}$ depth, recorded during the underway legs (operation of the undulating CTD). The anticyclonic gyre is evident but the speed distribution is not symmetrical: values appear to be higher (maximum of 50 $\mathrm{cm} \mathrm{s}^{-1}$ ) for the eastward component in the northern part than for the westward one in the south (maximum of $40 \mathrm{~cm} \mathrm{~s}^{-1}$ ).

We have compared data from drifters and ADCP along the central transect. The spatial distribution of the velocity components perpendicular to ship track at $10 \mathrm{~m}$ depth is very similar in both cases (Fig. 10). However, the ADCP records display lower values and

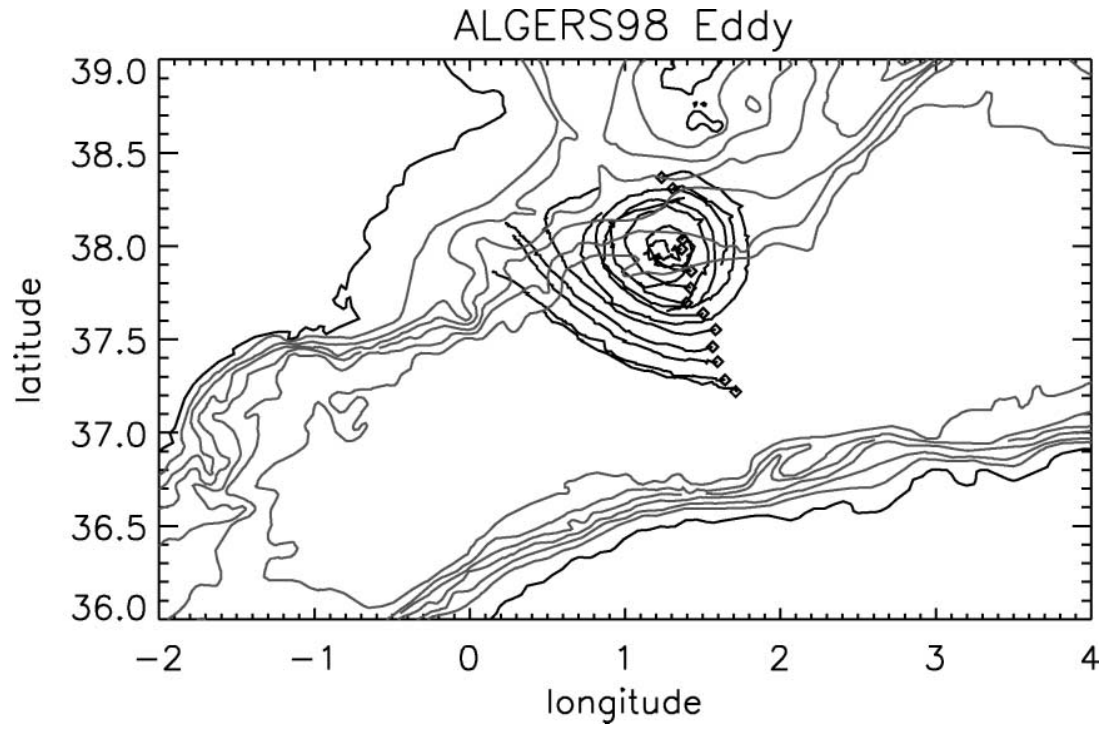

Fig. 9. Release points $(\diamond)$ and trajectories of the 15 drifting buoys deployed from 19 to 26 May 1998. 


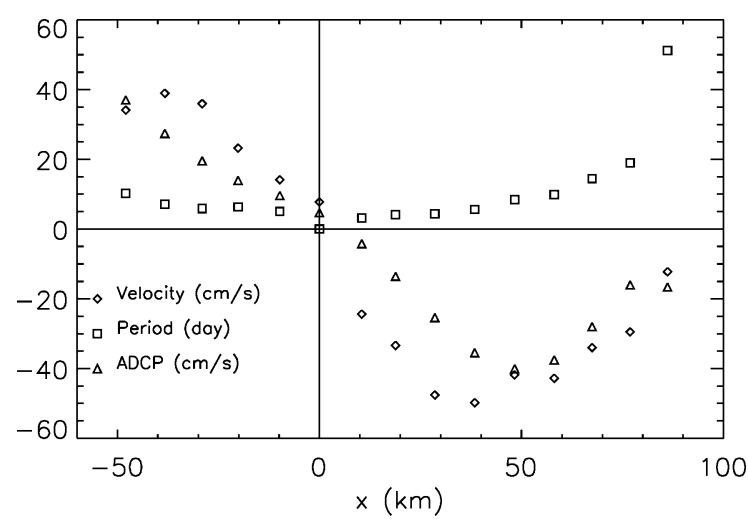

Fig. 10. Initial tangential velocity and period of rotation for the 15 drifters released across the eddy, plus ADCP velocity recorded at $10 \mathrm{~m}$.

the maximum speed (in the southern half of the section, where it can be precisely located) is reached $10 \mathrm{~km}$ further south. This disagreement is consistent with the differences observed in the analysed fields (Fig. 12A and B) and can be due to the time elapsed between both kinds of measurements, from 30 to $88 \mathrm{~h}$ depending on the location. In fact, in Fig. $12 \mathrm{C}$ the location of the eddy structure derived from CTD data is closer to the one derived from drifters than from ADCP.

An additional source of errors in building ADCP and drifters analysed surface fields is due to the uneven distribution of measurement points, with extrapolations to the border of the domain. Fig. 12D shows the difference between the velocity fields determined by drifters and by ADCP. The highest discrepancies are related to areas where no data existed for one or both sets and were extrapolated by the analysis scheme, as the upper left part of the domain.

Concerning the problem of the reference level for geostrophic computation, the position of the eddy, attached to the continental slope, does not allow using a common deepest level of no motion to compute geostrophic velocities. So, a reference level of no motion has been chosen at $1000 \mathrm{dbar}$, to allow the geostrophic computations to be done for most of the sampled domain. The three data sets recorded within a period of 8 days display the presence of the anticyclonic gyre, although there are small, but evident, discrepancies in both the eddy centre location and velocity distribution. The best representation of an anticyclonic eddy coincident with the hydrographic structure is obtained from the geostrophic computations, which is not surprising since the actual velocity measurements contain, especially near the surface, nongeostrophic components. However, the difference between geostrophic and actual velocity is slightly different, which suggests that there is no relevant cyclostrophic acceleration associated with the anticyclonic trajectory curvature. The importance of cyclostrophic acceleration relative to the Coriolis acceleration can be obtained using a simple analysis scale: $\left(V^{\wedge} 2 / R\right) /(f V)=V / f R$. Giving values of actual velocity at $10 \mathrm{~m}: 0.40 /\left(0.61 \times 10^{-4} \times 7 \times 10^{4}\right)=$ 0.09 . This confirms that the nongeostrophic component associated to the anticyclonic eddy is negligible and, hence, the geostrophic hypothesis is not critical (see for instance Gomis et al. (2001), where they describe an anticyclonic eddy which has a clear supergeostrophic signature, with a maximum difference of $20 \%$ between geostrophic and actual velocity).

The geostrophic surface velocity computed from SLA (Fig. 12E) has been interpolated into the same grid than in previous calculations. The presence of the anticyclonic eddy is in a very good agreement with in situ data, including the gyre centre location. However, the eddy structure appears smoother (weaker speeds, see Fig. $12 \mathrm{~F}$ for a comparison with geostrophic computation from CTD) and slightly elongated in the NW-SE direction. This can be the result of the filtering and interpolating methods over large scales used for the construction of the combined altimeter maps (Ayoub et al., 1998). This effect had been pointed out by previous authors (Vignudelli, 1997). In our case, the map has been built averaging data over a period in which the eddy was drifting to the west. In fact, the drifters trajectories during the weeks following the cruise show a tendency of the eddy to become elongated in such a direction, while the topographic interaction with the continental slope increased.

\subsubsection{Deep motion}

Fig. 13 shows the vertical distribution of geostrophic velocity along the central CTD section calculated using different levels of reference, to allow examining of the velocity structure along the whole 


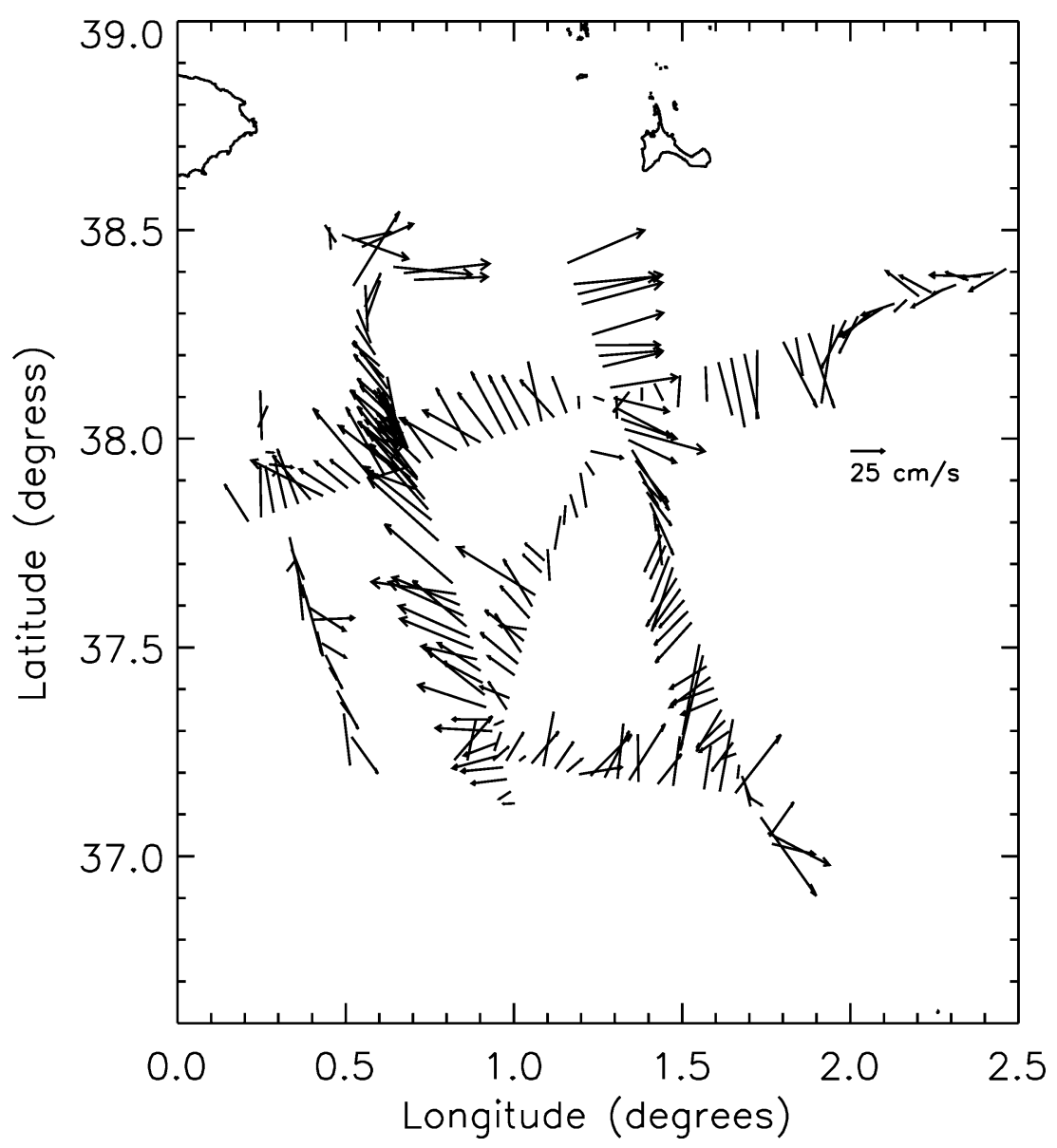

Fig. 11. ADCP velocity vectors recorded at $14 \mathrm{~m}$ and averaged every $10 \mathrm{~min}$.

eddy extension. In all cases, the sense of motion of the cross-section component fits clearly with an anticyclonic rotation everywhere in the domain, while the speed at the surface reaches values up to $35 \mathrm{~cm} \mathrm{~s}^{-1}$ at $50 \mathrm{~km}$ from the centre. Only a few spots of very weak (less than $1 \mathrm{~cm} \mathrm{~s}^{-1}$ ) reversed speeds are observed below 400 dbar, mainly between stations \#12 and \#13. Independently of the reference level, the general along-track change of sign in the velocity field is very well defined on the vertical of station \#9 (centre of the eddy).

The deep 3D-velocity structure can be examined by means of the analysed horizontal fields, using only one data source (CTD) with reference level of no motion at 2500 dbar. In this case, due to the bathy- metry, only the southern half of the domain can be calculated. The reconstructed velocity fields (Fig. 14) clearly show the anticyclonic eddy structure until 250 dbar. Below that, it begins to be distorted, although keeping a general negative vorticity, and in the deeper levels a well-marked, although very weak, anticyclonic gyre is seen again.

Finally, we have carried on a test using the surface geostrophic velocity field derived from the SLA map (Fig. 12D) as the barotropic component to transform the baroclinic relative into 'absolute' geostrophic velocities at the different depths (we do not analyse in detail the problem of reference level for geostrophic computation in order to avoid overlapping with other dynamical works in progress related with this data 

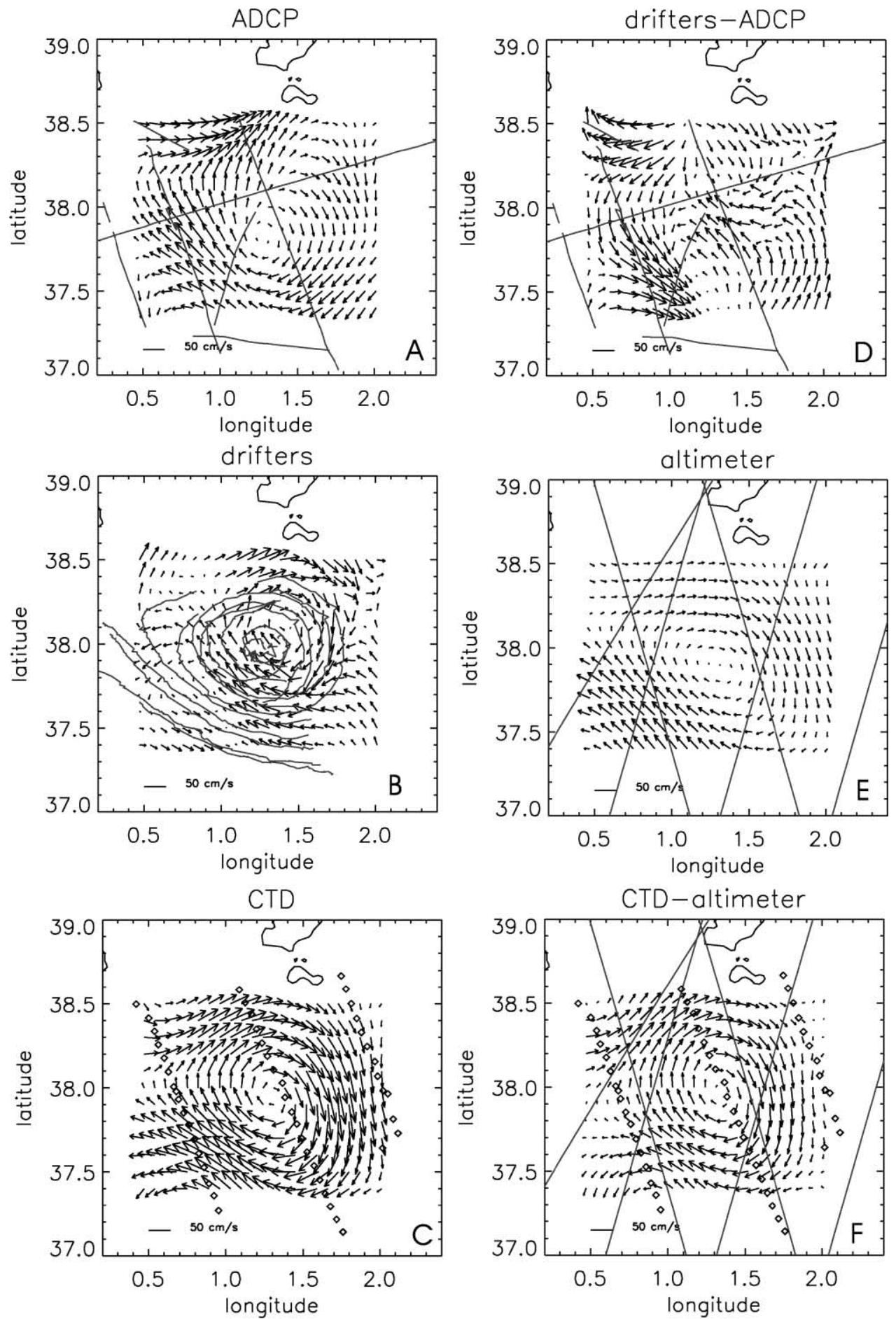

Fig. 12. Surface velocity field $(10 \mathrm{~m})$ generated from $(\mathrm{A})$ ADCP measurements $(\mathrm{B})$ drifters and $(\mathrm{C})$ geostrophic computations using a reference level of 1000. The difference between (B) and (A) is presented in (D), SLA maps (altimeter) in (E) and the difference between (C) and (E) is shown in $(F)$. 

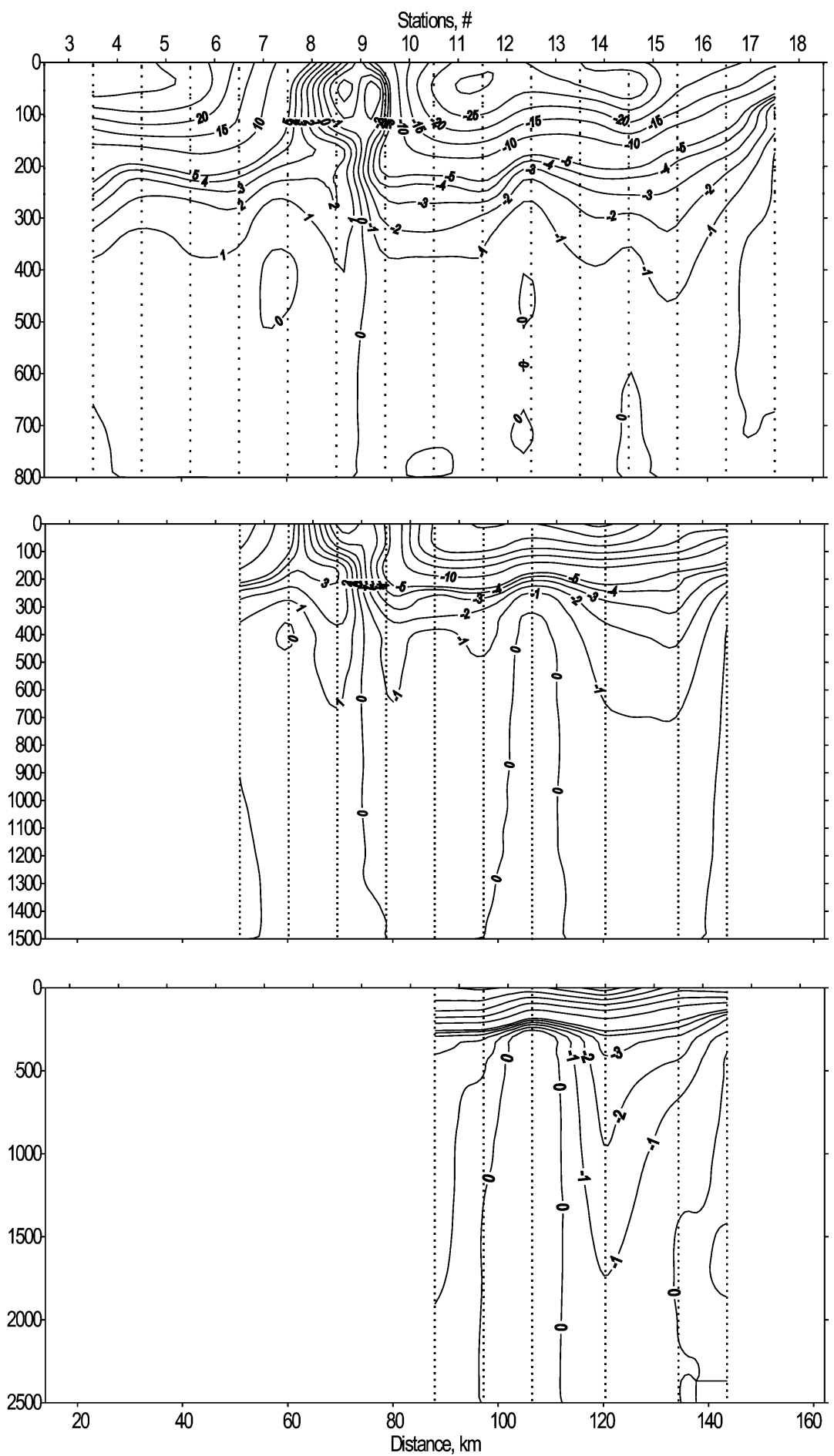

Fig. 13. Vertical distribution of geostrophic velocity across the eddy with reference level at 800,1500 and 2500 dbar. Left is north and right is south. Isolines are at $1 \mathrm{~cm} / \mathrm{s}$ intervals under $5 \mathrm{~cm} / \mathrm{s}$ and at $5 \mathrm{~cm} / \mathrm{s}$ above it. (Positive values into section.) 

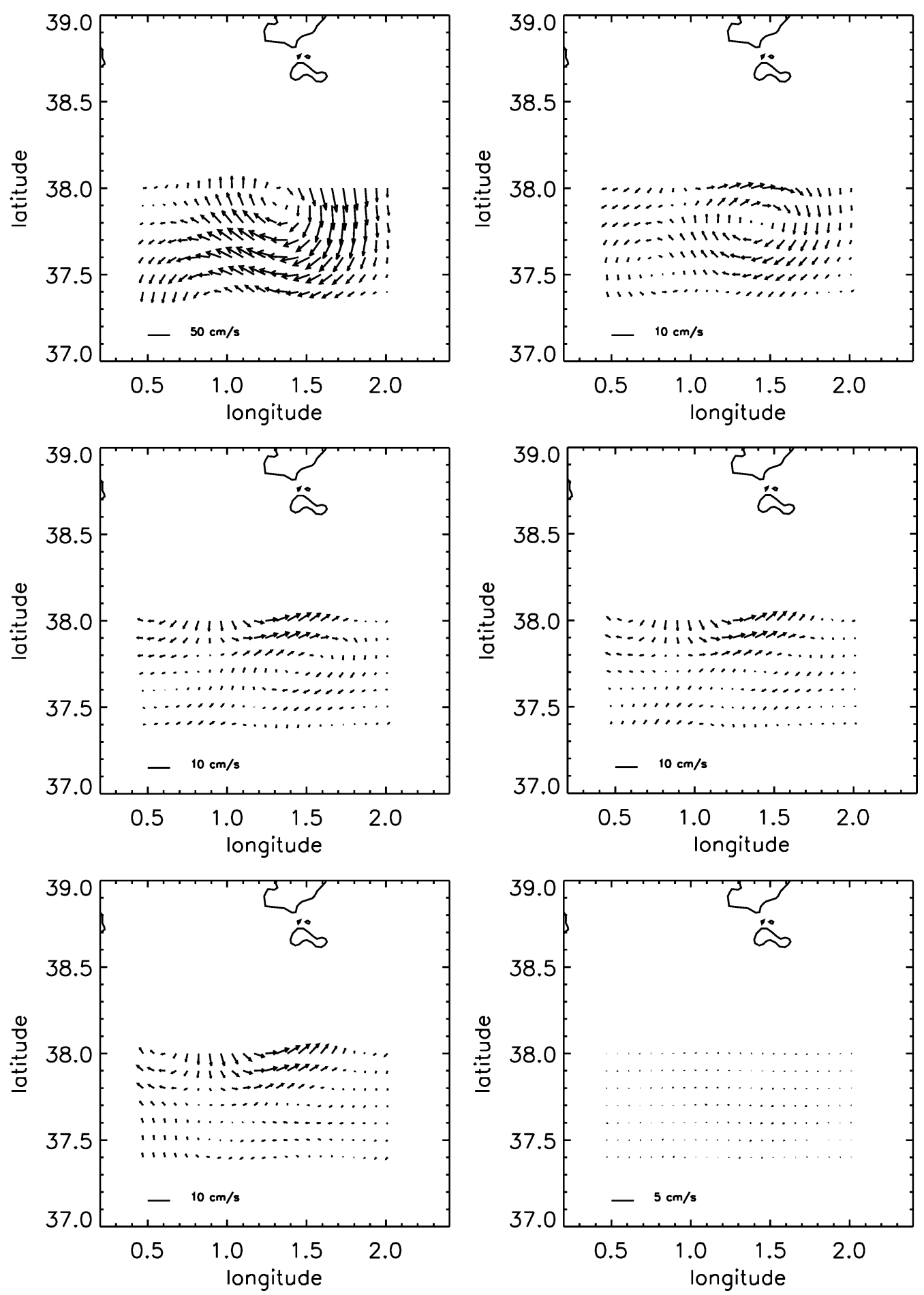

Fig. 14. Geostrophic velocity fields computed from CTD data using a reference level of no motion at 2500 dbar. From left to right and top to bottom: 50, 250, 500, 1000, 1500 and 2250 dbar. 
set). As the surface eddy detected by altimetry is weaker compared to the structure measured in situ, the resulting velocity fields (not shown) are also weaker. Subsequently, the baroclinic shear forces an inversion of the sense of rotation below $100 \mathrm{dbar}$, so that the eddy becomes clearly cyclonic. This is in contradiction with in situ data (ADCP) that until 250 $\mathrm{m}$, the deepest velocity measurements available still show an anticyclonic motion. Hence, the SLA map, in spite of providing the kind of information needed for geostrophic calculations (sea surface slope), is too coarse to compute the eddy barotropic velocity with an accuracy to resolve the deep motion.

Independently from velocity measurements or indirect calculations, the penetration in depth of an anticyclonic eddy detected in the surface can be diagnosed from theoretical assumptions. Gill (1981) analysed the problem of a homogeneous intrusion in a stratified rotating fluid. He demonstrated that an intrusion with horizontal scale $L$, into an initially linearly stratified fluid with Brunt-Väisälä frequency $N$, will produce a density irregularity with a vertical scale of order $H \sim f L / N$, where $f$ is the Coriolis parameter. Introducing in this formula the typical values obtained during our eddy observations $\left(f \sim 10^{-4} \mathrm{~s}^{-1}, L \sim 10^{5}\right.$ and $N \sim 10^{-3} \mathrm{~s}^{-1}$ ) we obtain $H>2000 \mathrm{~m}$. This is a rather rough estimation but consistent with the results of our observations.

\section{Summary and discussion}

During the May 1998 MATER cruise, an open sea mesoscale eddy in the Algerian Basin has been sampled for the first time from the surface to the bottom, at $2800 \mathrm{~m}$. CTD casts, ADCP velocity profiles and Lagrangian surface drifters have allowed a characterisation of the surface velocity field and the hydrographic structure in the whole water depth. In the upper levels, we have reported small differences (a few centimetres per second) between actual and geostrophic currents, which suggest the absence of significant ageostrophic motion associated to the gyre. The successive position of the different drifters presents the image of an almost solid-body rotation in an inner zone of 80-km diameter, with maximum velocities of $50 \mathrm{~cm} \mathrm{~s}^{-1}$ in the south. The differences between ADCP and drifters data at upper levels (10 $\mathrm{m}$ ) in terms of magnitude and position of the eddy are due to the time elapsed between both kinds of measurements. Concerning the geostrophic computations, we have found that independently of the reference level chosen, there is a clear change of sign in the velocity field, which is defined on the vertical of CTD station \#9.

We have identified an intermediate degree of MAW mixing, comparing the hydrographic properties of the centre of the eddy with hydrographic properties of the Algerian current and the open sea eddies in the eastern Algerian Basin. This clearly accounts for the origin of the eddy from the Algerian current and its further drift in the open basin. Concerning the presence of the eddy at deep levels, although the signal is very weak, the geostrophic computations evidence an anticyclonic rotation and the nearly circular structure with lighter water in the centre is well marked by the horizontal analysis of density field.

\section{Acknowledgements}

The authors are grateful to the HESPERIDES master and crew, as well as to all the colleagues on board, for their efficient cooperation. The cruise was funded by the Spanish National $R+D$ Plan under grants MAR96-2585-C03-CE and MAR97-1930-E. Satellite infrared images previous to the cruise were obtained from DLR, Germany. The altimetric maps were provided by CLS, Toulouse. This paper is a contribution to the MATER (contract MAS3-CT960051) project.

\section{References}

Allen, J.T., Smeed, D.A., Crisp, N., Ruiz, S., Watss, S., Velez, P.J., Jornet, P., Rius, O., Castellon, A., 1997. Upper ocean underway operations on BIO Hesperides cruise OMEGA-ALGERS using SeaSoar and ADCP. Internal Document No. 17, Southampton Oceanography Centre.

Ayoub, N., Le Traon, P.Y., De Mey, P., 1998. A description of the Mediterranean surface variable circulation from combined ERS1 and TOPEX/POSEIDON altimetric data. J. Mar. Sys. 18, $3-$ 40.

Benzohra, M., Millot, C., 1995a. Characteristics and circulation of the surface and intermediate water masses off Algeria. Deep-Sea Res. 42 (10), 1803-1830.

Benzohra, M., Millot, C., 1995b. Hydrodynamics of an open sea Algerian eddy. Deep-Sea Res. 18 (2), 1831-1847. 
Bretherton, F.P., Davis, R.E., Fandry, C.B., 1976. A technique for objective analysis and design of oceanographic experiments applied to MODE-73. Deep Sea Research I 23, 559-582.

Bouzinac, C., Vázquez, J., Font, J., 1998. CEOF analysis of ERS-1 and TOPEX/POSEIDON combined altimetric data in the region of the Algerian current. J. Geophys. Res. 103 (C4), 8059-8071.

Emelianov, M.V., Millot, C., Font, J., Taupier-Letage, I., 1999. New data on Levantine intermediate water circulation in the western Mediterranean Sea. In: Zatsepin, A. (Ed.), Oceanic Fronts and Related Phenomena. Konstantin Fedorov Memorial Symposium Proceedings. IOC Wokshop Report. UNESCO, Paris, pp. $132-$ 137.

Font, J., Millot, C., Salas, J., Julià, A., Chic, O., 1998a. The drift of modified Atlantic water from the Alboran Sea to the eastern Mediterranean. Sci. Mar. 62 (3), 211-216.

Font, J., et al., 1998b. MATER3 report. Cruise report (WWW pages: http://www.icm.csic.es/geo/gof/ra/algers98/).

Fuda, J.L., Millot, C., Taupier-Letage, I., Send, U., Bocognano, X., 2000. XBT monitoring of a meridian section across the western Mediterranean Sea. Deep-Sea Res. 47 (11), 2191-2218.

Gill, A.E., 1981. Homogeneous intrusion in a rotating stratified fluid. J. Fluid Mech. 103, 275-295.

Gomis, D., Ruiz, S., Pedder, M.A., 2001. Diagnostic analysis of the 3D ageostrophic circulation from a multivariate spatial interpolation of CTD and ADCP data. Deep-Sea Res. 48, 269-295.

Griffiths, G., 1994. Using 3DF GPS heading for improving underway ADCP data. J. Atmos. Ocean Tech. 11, 1135-1143.

Isern-Fontanet, J., Salas, J., Ruiz, S., Font, J., Millot, C., 2000. Tracking anticyclonic open-sea eddies in the Algerian basin by altimetry. In: Bostater Jr., C.R., Santoleri, R. (Eds.), Remote Sensing of the Ocean and Sea Ice 2000. Proc. SPIE, vol. 4172, pp. $37-43$.

Iudicone, D., Santoleri, R., Marullo, S., Gerosa, P., 1998. Sea level variability and surface eddy statistics in the Mediterranean Sea from TOPEX/POSEIDON data. J. Geophys. Res. 103 (C2), 2995-3011.

Le Traon, P.-Y., Nada, F., Ducet, N., 1998. An improved mapping method of multiva-satellite altimeter data. J. Atmos. Ocean Tech. $15,522-534$.
Millot, C., 1985. Some features of the Algerian current. J. Geophys. Res. 90, 7169-7176.

Millot, C., 1994. Models and data: a synergetic approach in the western Mediterranean Sea. In: Malanotte-Rizzoli, P., Robinson, A.R. (Eds.), Ocean Processes in Climatic Dynamics: Global and Mediterranean Examples. Kluwer Academic Publishing, Norwell, MA, pp. 407-425.

Millot, C., 1999. Circulation in the Western Mediterranean Sea. J. Mar. Sys. 20, 423-442.

Millot, C., Benzohra, M., Taupier-Letage, I., 1997. Circulation in the Algerian basin inferred from the MEDIPROD-5 current meters data. Deep-Sea Res. 44 (9-10), 1467-1495.

Morán, X.A.G., Taupier-Letage, I., Vázquez-Domínguez, E., Ruiz, S., Arín, L., Raimbault, P., Estarda, M., 2001. Physical-biological coupling in the Algerian basin (SW Mediterranean): influence of mesoscale instabilities on the biomass and production of phytoplankton and bacterioplankton. Deep-Sea Res. 48, $405-437$.

Obaton, D., Millot, C., Chabert d'Hières, G., Taupier-Letage, I., 2000. The Algerian current: comparisons between in situ and laboratory measurements. Deep-Sea Res. 47 (11), 2159-2190.

Pedder, M.A., 1993. Interpolation and filtering of spatial observations using successive corrections and Gaussian filters. Mon. Weather Rev. 121, 2889-2902.

Puillat, I., Taupier-Letage, I., Millot, C., 2002. Algerian eddies lifetime can near 3 years. J. Mar. Syst. 31, 245-259.

Ruiz, S., 2000. Análisis espacial objetivo de datos oceanográficos: aplicaciones en el mar de Alboran. PhD Thesis, Universidad Politécnica de Cataluña, 168 pp.

Salas, J., 1999. Estudio Lagrangeano de la circulación superficial en la cuenca Argelina (mar Mediterráneo occidental). PhD Thesis, Universidad Politécnica de Cataluña, Barcelona, 177 pp.

Taupier-Letage, I., 2000. The ELISA experiment WWW pages: http://www.com.univ-mrs.fr/LOB/ELISA/index.html.

Taupier-Letage, I., Millot, C., 1988. Surface circulation in the Algerian basin during 1984. Oceanol. Acta sp. 9, 119-131.

Vignudelli, S., 1997. Potential use of ERS-1 and Topex/Poseidon altimeters for resolving oceanographic patterns in the Algerian basin. Geophys. Res. Lett. 24 (14), 1787-1790. 